\begin{tabular}{|l|l|l|l|l|}
\hline Jurnal Penelitian \& PKM & Juli 2017 & Vol 4, No: 2 & Hal: $129-389$ & ISSN \\
$2442-448 X(p), 2581-1126(e)$
\end{tabular}

\title{
PERAN KELUARGA DALAM MENANGGULANGI KENAKALAN REMAJA
}

\author{
OLEH: \\ ERIESKA GITA LESTARI ${ }^{1}$, SAHADI HUMAEDI ${ }^{2}$, MELAINNY BUDIARTI S. ${ }^{3}$, DESSY HASANAH ${ }^{4}$ \\ 1. Mahasiswa Program Studi Sarjana (S-1) IImu Kesejahteraan Sosial Fakultas IImu Sosial dan IImu Politik Universitas Padjadjaran \\ 2. Pusat Studi Kewirausahaan Sosial, CSR, dan Pengembangan Masyarakat Fakultas Ilmu Sosial dan Ilmu Politik Universitas Padjadjaran \\ 3. Pusat Studi Kesejahteraan Anak dan Keluarga Fakultas IImu Sosial dan Ilmu Politik Universitas Padjadjaran \\ 4. Departemen Kesejahteraan Sosial Fakultas IImu Sosial dan IImu Politik Universitas Padjadjaran
}

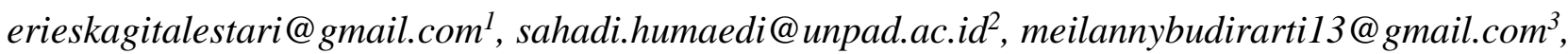
dessy@unpad.ac.id ${ }^{4}$
\end{abstract}

\begin{abstract}
ABSTRAK
Masa remaja merupakan suatu periode yang penuh dengan perubahan serta rentan munculnya masalah terutama dalam kenakalan remaja. Perlu adanya perhatian khusus serta pemahaman yang baik serta penanganan yang tepat terhadap remaja merupakan faktor penting bagi keberhasilan remaja di kehidupan selanjutnya, mengingat masa transisi remaja merupakan masa yang paling menentukan. Selain itu perlu adanya kerjasama dari remaja itu sendiri, orang tua, guru dan pihak-pihak lain yang terkait agar perkembangan remaja di bidang pendidikan dan bidang-bidang lainnya dapat dilalui secara terarah, untuk mengurangi benturan gejolak remaja dan untuk memberi kesempatan agar remaja dapat mengembangkan dirinya secara optimal, perlu diciptakan kondisi lingkungan terdekat yang sestabil mungkin, khususnya lingkungan keluarga. Keadaan keluarga yang ditandai dengan hubungan suami-istri yang harmonis akan lebih menjamin remaja bisa melewati masa transisinya dengan mulus dan tidak merasa terganggu. Adapun beberapa peran yang dapat dilakukan orang tua dalam menanggulangi kenkalan remaja meliputi; Orangt ua harus menjadi teladan sikap dan ucapan pada anaknya, motivasi anak, orangtua memberi arahan dengan siapa dan di komunitas mana remaja harus bergaul. Orang tua berusaha menciptakan keluarga yang harmonis, komunikatif, dan nyaman bagi remaja. serta membantu remaja pandai memilih teman dan lingkungan yang baik remaja.
\end{abstract}

Kata Kunci: Peran Keluarga, Menanggulangi, Kenakalan Remaja.

\begin{abstract}
ABSTRACK
Adolescence is a period filled with changes and vulnerable to the emergence of problems or juvenile delinquency. For that we need special attention as well as a good understanding and proper handling of juveniles is an important factor for the success of young people in the next life, this is a time to remember the most decisive. Besides, it needs the cooperation of the teens themselves, parents, teachers and other parties concerned to adolescent development in education and other areas can be traversed in a focused, healthier and happier. To reduce conflicts of adolescent turmoil and to provide opportunities for teens to develop themselves optimally, need to be created nearby environmental conditions as stable as possible, especially the family environment. Family circumstances characterized by conjugal harmony will ensure teens get through the transition smoothly and
\end{abstract}


undisturbed. As for some roles do parents in tackling juvenile kenkalan include; Parents should be exemplary attitude and speech for young, motivation of children, parents provide direction with whom and in communities where teens have to get along. Parents trying to create a harmonious family, communicative, and convenient for teens. and to help teenager good at choosing friends and a good environment for young.

Keywords: Family Role, Overcome, Juvenile Deliquency.

\section{Pendahuluan}

Masa remaja erat kaitannya dengan kenakalan remaja. Masa remaja secara umum merupakan masa peralihan atau transisi dari masa anak-anak ke masa remaja. Sebenarnya kenakalan remaja itu timbul akibat dari ketidakmampuan anak dalam menghadapi tugas perkembangan remaja yang harus dipenuhinya. Pada masa remaja banyak sekali perubahan yang terjadi pada diri anak, baik segi psikis maupun fisiknya. Dalam segi psikis bayak teori-teori perkembangan yang memaparkan ketidakselarasan, gangguan emosi dan gangguan perilaku sebagai akibat dari tekanan-tekanan yang dialami remaja karena perubahan-perubahan yang terjadi pada dirinya maupun akibat perubahan pada lingkungan. Jika tidak diwaspadai, perubahanperubahan psikis yang terjadi sebagai tugas perkembangan remaja itu akan berdampak negatif pada remaja.

Salah satu faktor yang diyakini oleh masyarakat untuk dapat membendung dan mengurangi resiko negatif dari perkembangan pada masa remaja adalah dengan memberikan pendidikan agama dan menanamkan nilai-nilai agama pada anak sejak kecil. Perkembangan agama pada masa anak, terjadi melalui pengalaman hidupnya sejak kecil, dalam keluarga, di sekolah dan dalam lingkungan masyarakat. Semakin banyak pengalaman yang bersifat agama, (sesuai dengan ajaran agama) dan semakin banyak unsur agama, maka sikap, tindakan, kelakuan dan caranya menghadapi hidup akan sesuai dengan ajaran agama.
Di samping pemahaman terhadap ajaran agama, orang tua dalam mendidik dan mengasuh anak pun harus mengerti dasardasar pendidikan. Menurut Zakiah Daradjat apabila pendidikan dan perlakuan yang diterima oleh si anak sejak kecil merupakan sebab-sebab pokok dari kenakalan anak-anak, maka setiap orang tua haruslah mengetahui dasar-dasar pengetahuan, minimal tentang jiwa si anak dan pokok-pokok pendidikan yang harus dilakukan dalam menghadapi bermacam-macam sifat si anak.

Untuk membekali orang tua dalam menghadapi persoalan anak-anaknya yang dalam umur remaja, orang tua perlu pengertian sederhana tentang. Ciri-ciri psikologi remaja:

1. Kenakalan remaja meliputi semua perilaku yang menyimpang dari norma-norma hukum pidana yang dilakukan oleh remaja. Perilaku tersebut akan merugikan dirinya sendiri dan orang-orang di sekitarnya.

Para ahli pendidikan sependapat bahwa remaja adalah mereka yang berusia 13-18 tahun. Pada usia tersebut, seseorang sudah melampaui masa kanak-kanak, namun masih belum cukup matang untuk dapat dikatakan dewasa. Ia berada pada masa transisi. Masalah kenakalan remaja mulai mendapat perhatian masyarakat secara khusus sejak terbentuknya peradilan untuk anakanak nakal (juvenile court) pada 1899 di Illinois, Amerika Serikat. 
Kenakalan remaja menjadi hal yang perlu di waspadai dan lebih diperhatikan karena seiring berkembangnya seorang anak, sudah sewajarnya seorang remaja melakukan sebuah kenakalan. Selama kenakalan itu masih pada tingkat yang wajar. Oleh karena itu peran orang tua dalam mendidik seorang anak apalagi remaja sangat diperlukan penanaman nilai, dan norma yang diberikan sejak dini dapat mempengaruhi sikap, perbuatan mental seorang anak untuk dapat memilah mana hal yang perlu ditiru, dan mana hal yang tidak patut ditiru, pada intinya seorang anak dapat melihat mana yang baik dan mana yang tidak baik.

Apabila peran orang tua tidak maksimal sejak anak masih kecil, pada saat tumbuh menjadi seorang remajapun tidak menutup kemungkinan seorang remaja berbuat hal yang melanggar aturan. Seperti banyak contoh yang terjadi, seorang remaja kedapatan sedang merokok, meminum-minuman keras, sampai seks bebas dilakukan tanpa rasa bersalah. Hal itu karena tidak adanya pengawasan orang tua, atau kurangnya perhatian dari orang tua.

2. Banyak faktor-faktor yang membuat remaja memasuki dunia pergaulan yang rusak. Biasanya hal ini berawal dari mereka berteman dengan teman yang membawa dampak buruk, karena masa remaja itu masa dimana keadaan psikis remaja bisa mudah terpengaruh. Ada faktor yang berasal dari keluarga, karena kurangnya perhatian dari keluarga membuat anak menjadi royal dalam pergaulan.

3. Faktor terpenting yang membuat remaja mudah terjerumus dalam pergaulan bebas adalah karena kurangnya pemahaman agama yang diyakini dapat membentengi pikiran dan jiwa anak. Oleh karena itu, pendidikan dasar agama pada anak sangat diperlukan dalam kehidupan remaja. Berhasil atau tidak berhasilnya anak, kembali lagi pada peran keluarga dalam memberikan pendidikan agama dan pada diri anak sendiri. Maka dari itu seorang guru harus berusaha agar keluarganya baik dan tidak korupsi agar ia dapat mengajari kepada muridmuridnya yang merupakan remaja generasi penerus bangsa memiliki moral dan ahlak baik dan tidak korupsi, berusaha tidak berbohong agar muridm-uridnya sebagai remaja yang baik tidak menjadi pendusta, tidak terjaebak dalam kenakalan remaja.

\section{Metode}

Artikel ini disusun dengan menggunakan kajian literatur dan dokumentasi, yaitu literatur barupa buku-buku, makalah ataupun jenis tulisan lainnya dan juga kajian terhadap berbagai macam dokumen yang terkait dengan topik peran keluarga dalam menanganai kenakalan remaja yang diangkat dalam artikel ini.

\section{Pembahasan}

\section{Pengertian Kenakalan Remaja}

Kenakalan remaja meliputi semua perilaku yang menyimpang dari norma-norma hukum pidana yang dilakukan oleh remaja. Perilaku tersebut akan merugikan dirinya sendiri dan orangorang disekitarnya. Para ahli pendidikan sependapat bahwa remaja adalah mereka yang berusia 13-18 tahun. Pada usia tersebut, seseorang sudah melampaui masa kanak-kanak, namun masih belum cukup matang untuk dapat dikatakan dewasa. Adapun Jenis-jenis kenakalan remaja:

1) Penyalahgunaan narkoba

2) Seks bebas 


\begin{tabular}{|c|c|c|c|c|}
\hline Jurnal Penelitian \& PKM & Juli 2017 & Vol 4, No: 2 & Hal: $129-389$ & $\begin{array}{c}\text { ISSN } \\
2442-448 X(p), 2581-1126(e)\end{array}$ \\
\hline
\end{tabular}

3) Tawuran antara pelajar

Menurut M. Arifin penanggulangan kenakalan remaja dapat dibagi dalam pencegahan yang bersifat umum dan pencegahan yang bersifat khusus. Remaja perlu diperhatikan masa perkembangannya agar dapat melakukan pembimbingan yang tepat agar terhindar dari kenakalan remaja. Remaja dalam perkembangan umurnya akan mengalami periode perkembangan fisik dan psikis sebagai berikut:

1) Masa pra-pubertas (12 - 13 tahun)

Masa ini disebut juga masa pueral, yaitu masa peralihan dari kanak-kanak ke remaja. Pada anak perempuan, masa ini lebih singkat dibandingkan dengan anak laki-laki. Pada masa ini, terjadi perubahan yang besar pada remaja, yaitu meningkatnya hormon seksualitas dan mulai berkembangnya organ-organ seksual serta organ-organ reproduksi remaja. Di samping itu, perkembangan intelektualitas yang sangat pesat jga terjadi pada fase ini. Selain itu, pada masa ini remaja juga cenderung lebih berani mengutarakan keinginan hatinya, lebih berani mengemukakan pendapatnya, bahkan akan mempertahankan pendapatnya sekuat mungkin. Hal ini yang sering ditanggapi oleh orang tua sebagai pembangkangan. Remaja tidak ingin diperlakukan sebagai anak kecil lagi. Mereka lebih senang bergaul dengan kelompok yang dianggapnya sesuai dengan kesenangannya. Mereka juga semakin berani menentang tradisi orang tua yang dianggapnya kuno dan tidak/kurang berguna, maupun peraturanperaturan yang menurut mereka tidak beralasan, seperti tidak boleh mampir ke tempat lain selepas sekolah, dan sebagainya. Mereka akan semakin kehilangan minat untuk bergabung dalam kelompok sosial yang formal, dan cenderung bergabung dengan temanteman pilihannya. Misalnya, mereka akan memilih main ke tempat teman karibnya daripada bersama keluarga berkunjung ke rumah saudara. Tapi, pada saat yang sama, mereka juga butuh pertolongan dan bantuan yang selalu siap sedia dari orang tuanya, jika mereka tidak mampu menjelmakan keinginannya. Pada saat ini adalah saat yang kritis. Jika orang tua tidak mampu memenuhi kebutuhan psikisnya untuk mengatasi konflik yang terjadi saat itu, remaja akan mencarinya dari orang lain. Perhatian seolah-olah orang tua mengerti bahwa masalah itu berat sekali bagi remajanya, akan terekam dalam otak remaja itu bahwa orang tuanya adalah jalan keluar ang terbaik baginya. Ini akan mempermudah orang tua untuk mengarahkan perkembangan psikis anaknya.

2) Masa pubertas (14 - 16 tahun)

Masa ini disebut juga masa remaja awal, dimana perkembangan fisik mereka begitu menonjol. Remaja sangat cemas akan perkembangan fisiknya, sekaligus bangga bahwa hal itu menunjukkan bahwa ia memang bukan anak-anak lagi. Pada masa ini, emosi remaja menjadi sangat labil akibat dari perkembangan hormon-hormon seksualnya yang begitu pesat. Keinginan seksual juga mulai kuat muncul pada masa ini. Pada remaja wanita ditandai dengan datangnya menstruasi yang pertama, sedangkan pada remaja pria ditandai dengan datangnya mimpi basah yang pertama. Remaja akan merasa bingung dan malu akan hal ini, sehingga orang tua harus mendampinginya serta memberikan pengertian yang baik dan benar tentang seksualitas. Jika hal ini gagal ditangani dengan baik, perkembangan psikis mereka khususnya dalam hal pengenalan diri/gender dan seksualitasnya akan terganggu. Kasus-kasus gay dan lesbi banyak diawali dengan gagalnya perkembangan remaja pada tahap ini. Di samping itu, remaja mulai mengerti tentang gengsi, penampilan, dan daya 
tarik seksual. Karena kebingungan mereka ditambah labilnya emosi akibat pengaruh perkembangan seksualitasnya, remaja sukar diselami perasaannya. Kadang mereka bersikap kasar, kadang lembut. Kadang suka melamun, di lain waktu dia begitu ceria. Perasaan sosial remaja di masa ini semakin kuat, dan mereka bergabung dengan kelompok yang disukainya dan membuat peraturanperaturan dengan pikirannya sendiri.

3) Masa akhir pubertas (17 - 18 tahun)

Pada masa ini, remaja yang mampu melewati masa sebelumnya dengan baik, akan dapat menerima kodratnya, baik sebagai laki-laki maupun perempuan. Mereka juga bangga karena tubuh mereka dianggap menentukan harga diri mereka. Masa ini berlangsung sangat singkat. Pada remaja putri, masa ini berlangsung lebih singkat daripada remaja pria, sehingga proses kedewasaan remaja putri lebih cepat dicapai dibandingkan remaja pria. Umumnya kematangan fisik dan seksualitas mereka sudah tercapai sepenuhnya. Namun kematangan psikologis belum tercapai sepenuhnya.

4) Periode remaja Adolesen (19 - 21 tahun)

Pada periode ini umumnya remaja sudah mencapai kematangan yang sempurna, baik segi fisik, emosi, maupun psikisnya. Mereka akan mempelajari berbagai macam hal yang abstrak dan mulai memperjuangkan suatu idealisme yang didapat dari pikiran mereka. Mereka mulai menyadari bahwa mengkritik itu lebih mudah daripada menjalaninya. Sikapnya terhadap kehidupan mulai terlihat jelas, seperti cita-citanya, minatnya, bakatnya, dan sebagainya. Arah kehidupannya serta sifat-sifat yang menonjol akan terlihat jelas pada fase ini. Kenakalan remaja biasanya dilakukan oleh remaja-remaja yang gagal dalam menjalani proses-proses perkembangan jiwanya, baik pada saat remaja maupun pada masa kanakkanaknya. Masa kanakkanak dan masa remaja berlangsung begitu singkat, dengan perkembangan fisik, psikis, dan emosi yang begitu cepat. Secara psikologis, kenakalan remaja merupakan wujud dari konflik- konflik yang tidak terselesaikan dengan baik pada masa anak-anak maupun remaja para pelakunya. Seringkali didapati bahwa ada trauma dalam masa lalunya, perlakuan kasar dan tidak menyenangkan dari lingkungannya, maupun trauma terhadap kondisi lingkungan, seperti kondisi ekonomi yang membuatnya merasa rendah diri, dan sebagainya.

\section{Faktor Penyebab Kenakalan Remaja}

Seiring perkembangan zaman sudah melebihi batas yang sewajarnya. Banyak anak dibawah umur yang sudah mengenal rokok, narkoba, free-sex, dan terlibat banyak tindakan kriminal lainnya. Hal ini semua bisa terjadi karena adanya faktor-faktor kenakalan remaja berikut:

1) Kurangnya kasih sayang orang tua.

2) Kurangnya pengawasan dari orang tua

3) Pergaulan dengan teman yang tidak sebaya.

4) Peran dari perkembangan iptek yang berdampak negative

5) Tidak adanya bimbingan kepribadian dari sekolah.

6) Dasar-dasar agama yang kurang

7) Tidak adanya media penyalur bakat dan hobinya

8) Kebasan yang berlebihan

9) Masalah yang dipendam

Penyebab lain terjadinya kenakalan remaja disebabkan oleh faktor dari remaja itu sendiri (internal) maupun faktor dari luar (eksternal), yaitu: 


\section{Faktor Internal:}

1. Krisis identitas

Perubahan biologis dan sosiologis pada diri remaja memungkinkan terjadinya dua bentuk integrasi. Pertama, terbentuknya perasaan akan konsistensi dalam kehidupannya. Kedua, tercapainya identitas peran. Kenakalan ramaja terjadi karena remaja gagal mencapai masa integrasi kedua.

2. Kontrol diri yang lemah

Remaja yang tidak bisa mempelajari dan membedakan tingkah laku yang dapat diterima dengan yang tidak dapat diterima akan terseret pada perilaku 'nakal'. Begitupun bagi mereka yang telah mengetahui perbedaan dua tingkah laku tersebut, namun tidak bisa mengembangkan kontrol diri untuk bertingkah laku sesuai dengan pengetahuannya.

Faktor Eksternal:

1. Keluarga

Perceraian orangtua, tidak adanya komunikasi antar anggota keluarga, atau perselisihan antar anggota keluarga bisa memicu perilaku negatif pada remaja. Pendidikan yang salah di keluarga pun, seperti terlalu memanjakan anak, tidak memberikan pendidikan agama, atau penolakan terhadap eksistensi anak, bisa menjadi penyebab terjadinya kenakalan remaja.

2. Teman sebaya yang kurang baik

3. Komunitas/lingkungan tempat tinggal yang kurang baik.

Menurut Hurlock (1973) ada beberapa masalah yang dialami remaja yaitu:

1. Masalah pribadi, yaitu masalah-masalah yang berhubungan dengan situasi dan kondisi di rumah, sekolah, kondisi fisik, penampilan, emosi, penyesuaian sosial, tugas dan nilainilai.

2. Masalah khas remaja, yaitu masalah yang timbul akibat status yang tidak jelas pada remaja, seperti masalah pencapaian kemandirian, kesalahpahaman atau penilaian berdasarkan stereotip yang keliru, adanya hak-hak yang lebih besar dan lebih sedikit kewajiban dibebankan oleh orangtua.

\section{Simpulan}

Remaja masa kini memiliki tekanantekanan yang mereka dapatkan, mulai dari perkembangan fisiologi, ditambah dengan kondisi lingkungan dan sosial budaya serta perkembangan teknologi yang semakin pesat. Hal ini dapat mengakibatkan munculnya masalah-masalah psikologis berupa gangguan penyesuaian diri atau perilaku yang mengakibatkan bentuk penyimpangan perilaku yang disebut kenakalan remaja. Kenakalan remaja pada umumnya terjadi karena adanya tekanan-tekanan yang timbul dari lingkungan dan orang tua yang menginginkan anak melakukan peran dewasa, padahal mereka masih tergolong dalam masa remaja, secara psikologis anak belum mampu menghadapinya. Stres, kesedihan, kecemasan, kesepian, keraguan pada diri remaja membuat mereka mengambil resiko dengan melakukan kenakalan di usia remaja.

\section{Daftar Pustaka}

Kartono, Kartini Patologi Sosial 2 Kenakalan Remaja, Jakarta: PT Raja Grafindo Persada, 2010.

Raharjo, ST. 2015. Assessment untuk Praktik Pekerjaan Sosial dan Kesejahteraan Sosial. Bandung: Unpad Press 2015. Dasar Pengetahuan Pekerjaan Sosial. Bandung: Unpad Press. 2015. Keterampilan Pekerjaan Sosial: Dasar-dasar. Bandung, Unpad Press. 
Soekanto, Soerjono. 2009. Sosiologi Suatu Pengantar, Jakarta: PT. Raja Grafindo Persada.

Wirawan Sarwono, Sarlito. 1940. Psikologi Remaja, Jakarta: PT. Raja Grafindo Persada. http://www.g-excess.com/kenakalan-remajafaktor-penyebab-dan-tipsmenghadapinya.html

http://www.wawasanpendidikan.com/2015/02 /upaya-penanggulangan-kenakalanremaja.html 